Original Research Paper

\title{
Menggali Potensi Tanaman Porang Sebagai Tanaman Budidaya Pada Sistem Hutan Kemasyarakatan (HkM) Kabupaten Lombok Utara
}

\author{
Ismail Yasin ${ }^{1}$, Padusung ${ }^{1}$, Mahrup ${ }^{1}$, Igm Kusnara $^{1}$, Sukartono $^{1 *}$ Fahrudin $^{1}$

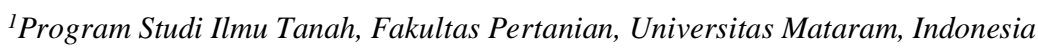

https://doi.org/10.29303/jpmpi.v3i2.983

Sitasi: Idrus, A. A., Ilhamdi, L., Mertha, I. G., Abidin, LL. A. M \& Yaquttunafis, L (2021). Konservasi Sumberdaya Alam Berwawasan Kearifan Lokal Melalui Sosialisasi Peningkatan Kesadaran Lingkungan Pada Masyarakat Desa Bagik Payung Timur, Lombok Timur. Jurnal Pengabdian Magister Pendidikan IPA, 4(3)

\section{Article history}

Received: 5 September 2021

Revised: 27 September 2021

Accepted: 29 September 2021

*Corresponding Author: Sukartono, Program Studi Ilmu Tanah, Fakultas Pertanian, Universitas Mataram, Indonesia, Email: kartono1962@unram.ac.id

\begin{abstract}
Tanaman porang (Amorphophallus oncophyllus) merupakan salah satu komoditi unggulan perkebunan akhir-akhir ini karena berniai ekonomi yang dapat dijadikan berbagai macam produk olahan, mulai dari makananan, kosmetik dan bahan baku industry lainnya. Tanaman umbian ini dapat tumbuh di semua kondisi agroklimat termasuk di kawasan hutan maupun lahan kebun dibawah tegakan pohon. Ada dua strategi pendekatan dalam mengatasi persoalan pengembangan porang yakni sosialisasi inovasi teknik budidaya tanaman porang (terdiri atas: perkembangbiakan menggunakan katak; perbanyakan menggunakan buah/biji; perbanyakan menggunakan umbi) dan yang kedua adalah pengolahan paska panen. Metode pelaksanaan pengabdian pada masyarakat telah dilakukan melalui penyuluhan teknik budidaya tanaman porang, peragaan budidaya tanaman porang di lahan garapan Kelompok Tani dan bimbingan teknik pengolahan pasca panen sederhana. Tanaman porang layak dikembangkan dalam pelestarian sumberdaya hutan, sebagai sarana pengalihan orientasi dan mata pencaharian masyarakat di sekitar hutan dari hasil hutan kayu ke hasil hutan non kayu dalam peningkatan kesejahteraan upaya melestarikan Kawasan penyangga. kandungan nutrisi dalam tanaman porang terbilang kompleks terutama pati, glukomannan, kristal kalsium oksalat, serat kasar dan gula reduksi. Penanganan porang pasca panen menghasilkan beragam bentuk baik berupa keripik (chip), tepung porang dan tepung glucomannan yang dapat digunakan sebagai bahan dasar tepung, mie instan dan produk makanan dan minuman lainnya. Persoalan yang dihadapi petani porang secara umum di lokasi yakni: 1) Permodalan; 2) Keamanan (sering terjadi pencurian tanaman porang di lahan); 3) Kebakaran hutan. Inovasi pembiakan porang berupa: 1) Pebiakan melalui katak atau bubil; 2) Pembiakan dari buah atau biji; 3) Pembiakan dari umbi.
\end{abstract}

Keywords: Porang; Hutan Kemasarakatan (HkM); Amorphophallus oncophyllus; Lombok Utara.

kesejahteraan masyarakat yang tinggal di sekitar kawasan hutan (Hariyanto, 2010).

HkM berfungsi sebagai sumber penghasilan

\section{Pendahuluan}

Regulasi dari Kementerian Kehutanan Republik Indonesia No.P-88/Menhut-II/2014, hutan kemasyarakatan $(\mathrm{HkM})$ adalah hutan negara yang pemanfaatannya ditujukan untuk pemberdayaan ekonomi bagi pengelolanya. Namun demikian tetap mempertahankan fungsinya sebagai pengendali keseimbanmgan ekosistem, tempat hidup dan berkembangbiaknya berbagai macam satwa liar dan 
tumbuhan serta sebagai sumber oksigen bagi seluruh makhluk hidup. Hutan juga mempunyai fungsi hidrologis sebagai pelindung dan penyedia sumberdaya air yang tentunya tak kalah penting bagi kebutuhan manusia (Hadi, 2016).

Agar dapat berfungsi sebagai pengendali keseimbangan ekosistem hutan sekaligus berfungsi sebagai pelindung sumberdaya air dan penyedia air untuk pertanian dan kebutuhan domestik HkM harus dikelola secara lestari dengan menerapkan kaidah konservasi ekosistem. Pengelolaan hutan secara lestari adalah suatu bentuk dan proses pengelolaan yang dilakukan sedemikian rupa sehingga secara terus menerus dapat memberikan produksi dan jasa sebagaimana yang diharapkan, tetapi tanpa mengurangi fungsinya sebagai hutan dan tidak menimbulkan dampak kerusakan lingkungan (Arif,2001). Hal ini mencakup menjaga keseimbangan luas lahan dari tanaman tegakan dan lahan untuk tanaman semusim, termasuk cara pengelolaan permukaan tanah yaitu cara pengolahan tanah dan penanaman tanaman penutup tanah.

Salah satu metode pengelolaan HkM yang dianjurkan adalah penerapan agroforestri (Ramdana dan Suhartati. 2015), dimana budidaya tanaman semusim dilakukan dalam lorong (bidang lahan selebar beberapa meter) yang dibatasi dengan baris pohon tegakan (pohon kayu dan buah-buahan) di sisi hulu dan hilir dari bidang lahan untuk budidaya tanaman semusim tsb. Metode agroforestry ini secara kontinyu dianjurkan oleh para LSM pendamping HkM, Namun demikian efektifitas dari anjuran tersebut masih rendah terbukti dengan masih banyaknya petani HkM yang mengerjakan lahannya seperti cara mengelola ladang mereka secara konvensional (seperti cara sebelumnya). Petani cenderung memperluas bidang lahan budidaya tanaman semusim dengan membiarkan pohon tegakan mati. Hal inilah yang membuat hutan HkM berada pada kondisi yang sangat buruk, jauh dari dari kondisi hutan lestari yang diharapkan dalam Kepmenhut.

Salah satu tanaman yang sedang memasuki fase popularitasnya adalah tanaman porong (Amorphophallus spp.) yang merupakan salah satu jenis tanaman etnobotani yang memiliki sejarah panjang dalam kehidupan masyarakat petani di Lombok. Umbi porang adalah pangan fungsional bagi masyarakat tani di lahan kering pulau Lombok. Tanaman ini hidup tanpa pengelolaan pada kawasan di sekitar hutan, ataupun pada kebun tradisional. Pada awalnya porang tidak dianggap memiliki potensi secara ekonomi. Domestikasi tanaman porong ke dalam sistem agroforestri dimungkinkan karena beberapa hal: (1) Porang dapat tumbuh hampir di semua jenis tanah, dengan rentang tempat tumbuh (berdasarkan tinggi tempat) dari dataran rendah hingga $1000 \mathrm{~m}$ dpl (Lahiya, 1993); (2) Porang tahan terhadap naungan dan dapat berproduksi atau menghasilkan umbi dengan baik meski tumbuh di bawah tegakan tanaman hutan (pohon) dengan tingkat naungan $>50 \%$ (Jansen et al., 1996); (3) Porang dapat dibudidayakan selama beberapa tahun (3-5 tahun) sebelum umbinya dipanen (Heyne, 1987); (4) Secara ekonomis porang sangat menjanjikan karena merupakan komoditas export dengan nilai harga tinggi; (5) Umbi porang memiliki banyak manfaat, yaitu sebagai bahan baku industri, bahan makanan, hingga bahan baku obat-obatan (Rosman dan Rusli, 1991). Tanaman porang termasuk tanaman berpenghasilan tinggi. Dalam luasan 1 ha, bisa ditanam sebanyak 6.000 batang porang, sehingga bisa menghasilkan 24 ton/ha, dengan demikian, bila setiap umbi dijual Rp 2.500 maka diperoleh hasil perkalian Rp 60 juta/ha per tahun (Ramadhani, 2020).

Kandungan glukomanan yang tinggi pada karbohidrat umbi porang menjadikannya memiliki potensi sebagai bahan yang dapat menyerap air dengan baik. Dari aspek konservasi kondisi ini dapat meningkatkan kapasitas infiltrasi, sehingga dapat menurunkan laju limpasan permukaan. Akan tetapi, seberapa besar peran tanaman porang tersebut sebagai agen konservatif pada tipologi lahan pertanian di Lombok belum ada laporan. Untuk itu maka penelitian ini akan mengkaji peran tanaman porang dalam konservasi tanah dan air pada tipologi lahan di Lombok Salah satu jenis tanaman yang sesuai dengan kondisi lingkungan HkM yang ideal adalah tanaman Porang (Amorphophallus muelleri. Blum).

Lahan di kawasan Lombok Utara ternyata memiliki toleransi terhadap sistem pertanian wanatani atau agroforestri. Sistem agroforestri diyakini sebagai salah satu solusi untuk mengatasi kerentanan tanah dan lahan terhadap proses degradasi. Keutamaan sistem tersebut terletak pada penggabungan tanaman tahunan atau tanaman hutan/pohon dan tanaman pertanian atau tanaman semusim. Hal ini memberi manfaat secara ekologis, 
sosial dan ekonomi (Herlina, 2016). Pada lahan yang tanahnya memiliki kesuburan rendah dan sensitif terhadap erosi, ternyata terkompensasi oleh keberadaan tanaman yang selalu ada sepanjang waktu, sehingga sistem wanatani (Agroforestri) dapat memberi manfaat jangka panjang sebagai sebuah model pertanian konservasi (conservation agriculture). Hal ini dimungkinkan karena dalam sistem agroforestri (Suprayogo et al., 2003) dapat tercipta daur karbon dan daur hara secara internal dan alami sehingga dalam jangka panjang lahan mengalami penyehatan secara berangsur-angsur. Di samping itu, pengkayaan bahan organik tanah, peningkatan kemantapan agregat tanah, dan akhirnya produktivitas tanah dapat meningkat, dan berkelanjutan.

Dua pendekatan yang yang dilakukan sebagai solusi dalam pengembangan tanaman porang di HkM Kabupaten Lombok Utara: a). Solusi dalam Budidaya Tanaman Porang: Perkembangbiakan menggunakan katak / bubil, Perbanyakan menggunakan buah/biji, Perbanyakan menggunakan umbi. b). Pengolahan Pasca Panen: Penanganan pasca panen umbi porang sederhana yang bisa diterapkan di kelompok tani, hal ini dilakukan untuk meningkatkan nilai jual tanaman porang.

\section{Metode}

\section{Penyuluhan Budidaya Tanaman Porang}

Penyuluhan dilaksanakan terhadap petani yang memiliki kelompok secara permanen. Materi penyuluhan disampaikan melalui diskusi kelompok terfokus (Focus Group Discussion, FGD). Metode FGD dapat diberikan kesempatan kepada setiap anggota dalam kelompok untuk mengemukakan pendapatnya, mengkritisi dan menyumbangkan pemikirannya terkait materi penyuluhan yang diberikan.

\section{Peragaan Budidaya Tanaman Porang di Lahan Garapan Kelompok Tani Ganda Suli Bakong Desa Sambik Elen, Bayan Lombok Utara}

Peragaan penanaman porang diikuti oleh anggota kelompok tani, PPL, petugas Desa atau petugas Dusun di Desa sasaran dengan memperkenalkan materi penyuluhan sebagai berikut:
Teknik Budidaya Porang

1) Perkembangbiakan menggunakan katak

Dalam $1 \mathrm{~kg}$ katak pada porang berisi sekitar 100 butir katak. Katak dapat Anda simpan pada saat melakukan proses pemanenan. Kemudian jika sudah memasuki musim penghujan, maka katak bisa Anda langsung tanam pada lahan yang telah dipersiapkan.

\section{2) Perbanyakan menggunakan buah/biji}

Tiap kurun waktu 4 tahun dalam budidaya porang tanaman ini akan menghasilkan bunga yang kemudian akan menjadi buah atau biji. Dalam satu tongkol buah tanaman porang bisa menghasilkan biji mencapai 250 butir. Biji tersebut bisa Anda gunakan sebagai bibit. Untuk menggunakannya Anda harus menyemaikannya terlebih dahulu.

\section{3) Perbanyakan menggunakan umbi}

Perbanyakan porang dapat menggunakan umbi. Umbi yang kecil ini dapat diperoleh dari hasil pengurangan tanaman yang sudah terlalu rapat. Oleh karena itu perlu untuk Anda kurangi. Dari hasil pengurangan tersebut, Anda bisa mengumpulkan umbi dengan ukuran yang kecil dan selanjutnya dapat dimanfaatkan sebagai bibit.

Bisa juga menggunakan umbi yang besar untuk perbanyakan tanaman porang. Langkah awal dengan memecah umbi tersebut menjadi ukuran yang kecil lalu kemudian bisa ditanam pada lahan yang telah disiapkan.

\section{Pengolahan Pasca Panen}

Penanganan pasca panen umbi porang cukup sederhana, seperti pembuatan chips porang. Umbi porang setelah dipanen, dilakukan pemilihan atau sortasi umbi kemudian dibersihkan dari kotoran (tanah yang masih lengket) menggunakan air, lalu diiris tipis-tipis dengan ketebalan 5-10 mm dan dikeringkan di bawah terik matahari (6 hari), hal ini dilakukan untuk meningkatkan nilai jual tanaman porang. Dimana umbi porang yang sudah di iris, harganya mencapai kisaran Rp. 15.000 - Rp. 25.000/kg(Sumber: Petani Porang Lombok Utara).

\section{Hasil dan Pembahasan}

\section{Prospek Pengembangan Tanaman Porang}

1. Pelestarian Vegetasi Tegakan Pada Kawasan HKM

Budidaya tanaman porang termasuk budidaya tanaman yang terbilang mudah dan 
perawatannya tidak seintensif tanaman musiman seperti padi, tembakau, palawija atau hortikultura. Tanaman Porang memiliki potensi tinggi dikembangkan dengan dibawah naungan vegetasi tegakan, seperti hutan kemasyarakatan (HkM), hal ini dikarenakan: a) Porang hanya dapat tumbuh dan berkembang dengan baik di bawah tegakan atau naungan dengan intensitas cahaya kurang lebih 50$70 \%$. Kegiatan budidaya porang secara tidak langsung menjaga vegetasi tegakan pada HkM karena dibutuhkan oleh petani sebagai naungan atau paying dalam menumbuhkan porang sehingga keberadaan hutan rakyat dalam waktu cukup lama; b) Mencegah terjadinya penggembalaan liar di dalam HkM, karena dapat merusak tanaman porang yang ada di dalamnya. c) Mencegah terjadinya kebakaran di kawasan HkM, karena akan mematikan perkembangan/kelestarian porang yang ada di dalamnya; dan d) HkM akan terproteksi oleh masyarakat di sekitarnya, karena dengan merusak hutan sama halnya dengan merusak budidaya tanaman porang; e) Mempunyai nilai ekonomis tinggi dan produktif.

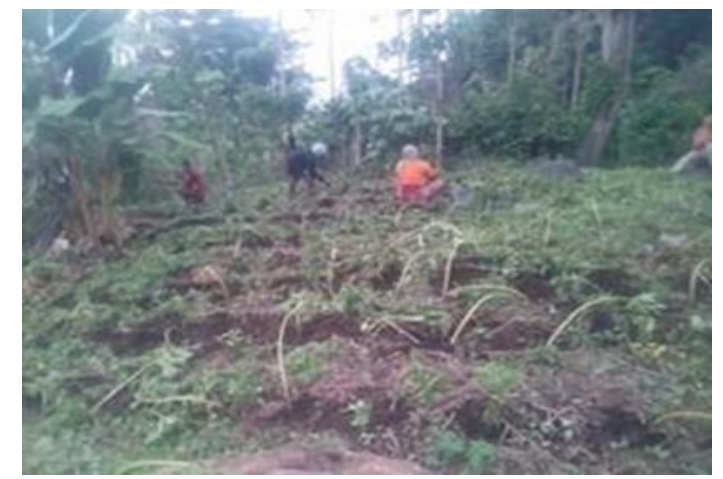

Gambar 1. Penanaman Porang pada HkM di sekitar Desa Sambik Elen Kecamatan Bayan Lombok Utara

2. Kandungan Nutrisi dan Pemanfaatan

Porang, seperti halnya dengan tanaman umbi-umbian lain juga mengandung karbohidrat, mengandung lemak, protein, mineral, vitamin dan serat pangan (Tabel 1). Karbohidrat merupakan komponen penting pada umbi porang yang terdiri atas pati, glukomannan, serat kasar dan gula reduksi. Kandungan glukomanan yang relatif tinggi merupakan ciri spesifik dari umbi porang (Tabel 3). Porang kuning (A. oncophyllus) dilaporkan mengandung glukomanan sekitar 55\% dalam basis kering, sementara porang putih (A. variabilis) sedikit di bawahnya, yakni 44\% (Koswara 2013). Umbi sejenis, seperti suweg (A. campanulatus) hanya mengandung 0-3,1\% glukomannan (Sulfiani 1993 dalam Mulyono 2010).

Tabel 1. Kandungan nutrisi ubi A. campanulatus, A. rivieri dan A. oncophyllus

\begin{tabular}{|l|c|c|c|}
\hline Nutrisi & A. campanulatus & A. rivieri & A. oncophylus \\
\hline Kadar air (\%) & $75-79$ & 78,8 & 83,30 \\
\hline Lemak (\%) & $0,4-2$ & 0,2 & 0,02 \\
\hline Protein (\%) & $1-5$ & 1,2 & 0,92 \\
\hline Karbohidrat (\%) & 18 & 19 & - \\
\hline Pati (\%) & $4,5-18$ & - & 7,65 \\
\hline Gula (\%) & 0,1 & - & - \\
\hline Mannan (\%) & $0-3$ & 44.3 & 55,5 \\
\hline Serat (\%) & 0,6 & 0,8 & 2,50 \\
\hline Kalsium (mg) & 50 & 43 & - \\
\hline Phospor (mg) & 20 & 22 & - \\
\hline Fe (mg) & 0,6 & 0,6 & - \\
\hline Vitamin A (iu) & 434 & 270 & - \\
\hline Energi (kj) & 420 & 340 & - \\
\hline
\end{tabular}

Sumber: Flach dan Rumawas (1996) 


\section{Glukomannan}

Mannan merupakan polisakarida yang ukuran granulanya 10-20 kali lebih besar daripada pati dan dapat dibedakan menjadi galaktomanan dan glukomanan berdasarkan bentuk ikatannya. Galaktomanan terdiri atas polimer D-galaktosa dan D-manosa dengan ikatan â-1,4 glikosida dan biasanya diekstrak dari biji tanaman ivory, nut, rumput laut dan ganggang (Koswara 2013). Galaktomannan memiliki ikatan seperti selulosa, namun memiliki BM lebih kecil. Polisakarida ini biasanya terdapat pada beberapa gum nabati, di antaranya Locus bean gum (mannose:galaktosa $=$ 4:1), guar gam (mannosa:galaktosa $=2: 1$ ), tara gum (mannosa:galaktosa $=3: 1)$, dan Fenugreek gum (mannose: galaktosa $=1: 1$ ).

Sementara glukomanan merupakan polisakarida yang tersusun oleh unit D-glukosa dan D-mannose. Bentuk ikatan yang menyusun polimer mannan adalah â-1,4-glikosida dan â-1,6-glikosida. Dalam satu molekul glukomanan terdapat 33\% Dglukosa dan $67 \%$ D-mannose $(1: 1,6)$ dengan BM 200.000 hingga 2.000.000 Dalton, bergantung pada jenis umbi porang, cara pengolahan dan lama penyimpanan (Keithley dan Swanson 2005). Gugus asetil terdapat pada setiap 6 hingga 19 gugus karbon pada posisi C-6 yang mempengaruhi kelarutan glukomanan dalam air dan perilaku gelatinisasinya saat dipanaskan (Chan 2009).

Menurut Wang dan Johnson (2003) dan Mulyono (2010), beberapa sifat/karakter penting glukomanan, antara lain:

- Larut dalam air dan membentuk massa yang kental dengan ke- mampuan mengembang yang cukup besar (138 hingga 200\%).

- Larutan kental tersebut bersifat seperti plastik dengan kekentalan mencapai 35.000 cps pada konsentrasi larutan $1 \%$, sehingga sangat sesuai untuk bahan pengental. Viskositas ini lebih tinggi dibandingkan dengan bahan pengental alami lainnya.

- Mampu membentuk gel; dengan penambahan air kapur, larutan kental glukomanan dapat membentuk gel yang khas dan tidak mudah rusak. Dengan pemanasan sampai 85 oC pada kondisi sedikit basa ( $\mathrm{pH} 9-10)$, terbentuk gel yang bersifat stabil dan irreversible, bahkan bila dipanaskan ulang pada suhu 100 hingga $200{ }^{\circ} \mathrm{C}$. Sifat ini sesuai untuk penggunaan glukomanan dalam pembuatan sejumlah makanan sehat untuk program penurunan berat badan, seperti cake, mie, kue kering, roti, sosis, bakso, dan makanan tiruan untuk vegetarian. Namun glukomanan dapat membentuk gel yang bersifat reversible bila dipanaskan bersama-sama dengan xanthan gum atau karagenan dan menunjukkan hasil sinergi yang baik pada $\mathrm{pH}$ 5,0. Sifat ini dimanfaatkan dalam pembuatan permen lunak, jeli, selai, yogurt, puding, dan es krim sebagai pengganti gelatin.

- Sifat perekat yang kuat dalam air, namun dengan penambahan asam asetat sifat tersebut akan hilang.

- Dapat diendapkan dengan etanol dan kristal yang terbentuk dapat dilarutkan kembali dengan asam klorida encer. Bentuk kristal yang diperoleh sama persis dengan bentuk kristal glukomanan di dalam umbi. Namun bila dicampur dengan larutan alkali akan terbentuk kristal baru yang berbentuk massa gel yang bersifat tidak larut dalam air maupun asam encer.

- Sifat mencair seperti agar.

- Stabil pada kondisi asam dan tidak menggumpal sampai pH di bawah 3,3.

- Toleran terhadap konsentrasi garam tinggi

- Mampu membentuk lapisan tipis (film) yang bersifat tembus pandang (jernih). Dengan penambahan $\mathrm{NaOH}$ atau gliserin, dapat dihasilkan film yang kedap air.

- Berdasarkan sifat-sifat tersebut, glukomanan dapat dimanfaatkan pada berbagai industri pangan, kimia, dan farmasi, antara lain untuk produk makanan, seperti konnyaku, shirataki (berbentuk mie); sebagai bahan campuran/tambahan pada berbagai produk kue, roti, es krim, permen, jeli, selai, dan lain-lain; bahan pengental pada produk sirup dan sari buah; bahan pengisi dan pengikat tablet; bahan pelapis (coating dan edible film); bahan perekat (lem, cat tembok); pelapis kedap air; penguat tenunan dalam industri tekstil; media pertumbuhan mikroba; dan bahan pembuatan kertas yang tipis, lemas, dan tahan air.

- Kadar glukomanan dalam umbi sangat ditentukan umur tanaman pada saat panen. Apabila tanaman dipanen pada satu periode tumbuh, kadar glukomanan dalam ubi berkisar antara $35-39 \%$. Kadar tersebut terus meningkat sejalan dengan umur panen yaitu 46-48\%, dan $47-55 \%$ masing-masing pada dua dan tiga periode tumbuh (Sumarwoto 2005). Namun 
dimulai saat tanaman mulai berbunga hingga biji mulai masak, kadar glukomanan menurun hingga 32-35\%. Oleh karena itu panen ubi sebaiknya dilakukan sebelum tanaman mulai berbunga.

\section{Kristal kalsium oksalat}

Sebagaimana tanaman famili Araceae lainnya, ubi porang juga mengandung kristal kalsium oksalat dan alkaloid yang tinggi. Di dalam tanaman, oksalat ditemukan dalam bentuk terlarut (asam oksalat) dan tidak larut yaitu kalsium oksalat. Kristal kalsium oksalat tersebut berbentuk jarum sehingga menyebabkan lidah dan tenggorokan terasa gatal dan panas saat dikonsumsi. Asam oksalat merupakan senyawa anti gizi yang dapat mengikat kalsium sehingga sulit diabsorpsi/ tidak tersedia bagi tubuh manusia, dan pada dosis tertentu bersifat toksik terhadap ternak (Nakata 2003). Pada dosis yang lebih tinggi, asam oksalat dan kristal kalsium oksalat menyebabkan abrasi mekanik pada saluran pencernakan dan tubulus halus dalam ginjal. Asam oksalat menyerap kalsium yang penting untuk fungsi saraf dan serat-serat otot. Pada kasus ekstrim, penyerapan kalsium ini menyebabkan hypocalcemia dan paralysis yang berakibat fatal (Brown 2000).

Menurut Chairiyah et al. (2011), kristal kalsium oksalat $(\mathrm{CaOx})$ dikelompokkan menjadi dua yaitu berukuran besar $(20-710 \mu \mathrm{m})$ dan kecil (1-15 $\mu \mathrm{m})$. Kerapatan kristal kalsium oksalat pada porang (A. muelleri Blume) yang terpapar sinar matahari tiga kali lebih banyak dibandingkan yang tidak terpapar. Daun memiliki jumlah kristal $\mathrm{CaOx}$ tertinggi per satuan luas, sedangkan umbi terendah. Adanya naungan atau tidak, juga tidak berpengaruh terhadap kerapatan kristal $\mathrm{CaOx}$ di bagian tepi atau tengah daun atau umbi. Indriyani et al. (2010) melaporkan bahwa suhu, curah hujan, persentase penutupan lahan oleh gulma, $\mathrm{pH}$ tanah, ketersediaan kalsium dalam tanah dan KTK tanah berpengaruh terhadap kandungan asam oksalat umbi porang. Hasil evaluasi umbi porang yang diperoleh dari beberapa lokasi menunjukkan bahwa kandungan asam oksalat umbi porang tertinggi diperoleh dari Desa Klino, Kabupaten Bojonegoro sebesar 7,74\% dan terendah di Desa Bendoasri, Kabupaten Nganjuk (2,33\%). Hasil analisis Smart PLS (Partial Least Square) menunjukkan adanya pengaruh langsung yang nyata antara tinggi tempat, dan CEC tanah dengan persentase penutupan kanopi, CEC tanah dengan diameter petiol, diameter petiol dengan diameter ubi, serta diameter petiol dengan kandungan oksalat ubi (Indriyani et al. 2011).

Keberadaan kalsium oksalat ini merupakan salah satu pembatas pemanfaatan porang sebagai bahan pangan. Namun, melalui perlakuan pendahuluan yang tepat sebelum pengolahan, seperti perendaman dalam larutan garam atau asam, sebagian besar kalsium oksalat dapat dihilangkan. Upaya ini juga perlu dilakukan dalam pengolahan porang menjadi tepung glukomanan yang akan dimanfaatkan sebagai bahan pangan.

\section{Respon Petani HKm Terhadap Ajakan Menanam Porang}

Respon petani (masyarakat) yang menjadi subjek penelitian ini terhadap ajakan menanam porang diperoleh dari hasil wawancara mendalam dengan responden terpilih bervariasi berdasarkan latar belakang sosial ekonomi dan umur responden. Yang pertama adalah kelompok petani yang sangat berminat (sangat antusias) dengan ajakan peneliti. Kelompok masyarakat ini pada umumnya adalah masyarakat atau petani yang sudah melek teknologi (dapat menggunakan gadget) atau internet di HPnya. Orang-orang ini walaupun baru mengenal tanaman porang ini setelah peneliti memperlihatkan contoh umbi porang (yang dibawa langsung ke responden) atau setelah peneliti memperlihatkan contoh tanaman porang di Youtube Langsung menunjukkan ketertarikannya untuk mengikuti program. Meskipun mereka belum pernah melihat porang sebelumnya, mereka sudah mengenal dua spesies lain dari marga (genus) Amorphophallus ini yaitu Suweg (Gawok) dan Iles-iles (Lombos). beberapa petani pernah membudidayakan Suweg sehingga mengenal rasa dan mempunyai pengalaman menanamnya (Pitojo, 2007). Beda Porang dengan Suweg yang paling jelas adalah dari umbinya yang berwarna putih susu sedangkan umbi porang berwarna kuning. Suweg juga tidak menghasilkan kathak (umbi daun) (Sumarwoto, 2005; Pitojo, 2007). Iles-iles berbeda dari porang karena batang iles-iles yang lebih kasar, tubuhnya lebih ramping dan umbinya lebih kecil dan berwarna keputih-putihan. Iles-iles juga tidak menghasilkan kathak. Bila Suweg sudah dibudidayakan oleh petani (karena umbinya bisa dimakan [bila petani kehabisan beras atau jagung]); sedangkan iles-iles (lombos) tetap menjadi 
tumbuhan liar yang tidak disukai keberadaannya. Iles-iles dan porang mempunyai getah umbi yang menimbulkan rasa gatal pada kulit manusia dan menyebabkan rasa gatal di tenggorokan kalau di makan. Itulah sebabnya mengapa petani selalu memandang sebelah mata pada kedua tumbuhan ini. Mungkin dulu waktu membuka lahan HKmnya ada tumbuhan porangnya kemudian dibuang karena dirasakan sangat mengganggu bagi petani yang mau menanam tanaman semusim. Bukti tentang dugaan adanya tumbuhan porang sebelum HKm dibuka adalah ditemukan banyaknya tumbuhan porang ini di kawasan hutan lindung Rinjani.

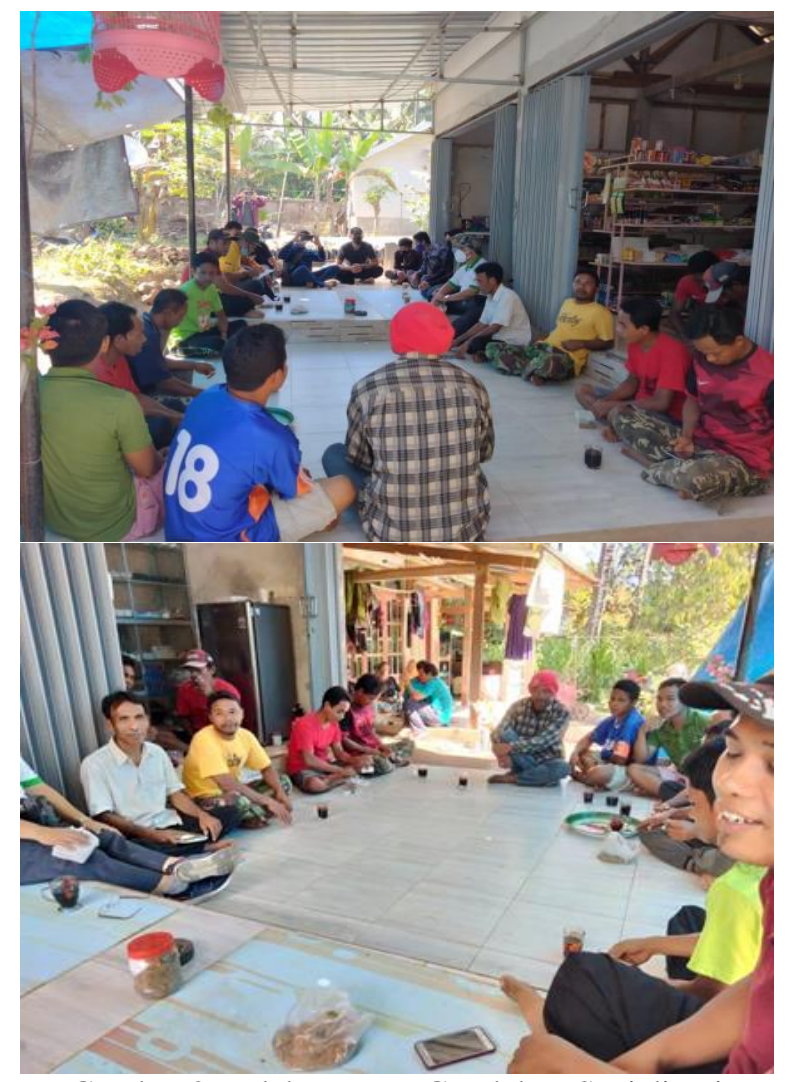

Gambar 2. Pelaksanaan FGD dalam Sosialisasi Penanaman Porang di HkM Kabupaten Lombok Utara.

Seiring dengan berjalannya waktu, dan sejalan dengan boomingnya pemberitaan media dan medsos tentang porang maka porang makin makin dikenal masyarakat, terutama kalangan muda yang sudah melek teknologi atau bisa menggunakan gadget mereka mengenal porang lewat gadgetnya.

Bagi petani yang berusia lanjut, buta aksara dan tidak mengenal teknologi maka responnya adalah tergantung pada apa yang ditawarkan peneliti. Ini biasanya berupa paket berupa benih (bibit) serta uang pemeliharaan selama tanaman tumbuh di lahannya. Mereka tidak terlalu tertarik dengan potensi hasil dan pendapatan porang yang diceritakan peneliti. Mereka pada dasarnya kurang percaya dengan informasi yang diberikan oleh peneliti atau informasi dari media. Mereka banyak belajar dari pengalamannya dibina atau didampingi oleh berbagai Lembaga Pemerintah maupun oleh LSM yang pada awal program dijejali dengan berbagai cerita muluk-muluk dan diakhir pembinaan, hasil binaannya tidak berlanjut karena berbagai alasan dan kondisi, sehingga kembali ke titik nol. Inilah yang menyebabkan petani kategori ini lebih tertarik dengan paket apa yang ditawari sebelum program yang ditawarkan diterapkan oleh petani.

Tipe petani yang ketiga adalah petani yang menggarap lahan $\mathrm{HKm}$ yang hak garapnya berdomisili diluar desa HKm. Sudah banyak hak garap dari lahan $\mathrm{HKm}$ sudah berpindah tangan. Hal ini disebabkan Pemegang hak garap pertama membutuhkan sejumlah uang tunai (terutama untuk biaya menjadi TKI, maka mereka terpaksa menjual hak garap lahan HKmnya. Hak garap ini kadangkadang berpindah ke orang bukan petani (PNS atau guru) yang bisa saja berdomisili di tempat yang sangat jauh. Pemegang hak garap yang semacam ini menitipkan lahan HKmnya pada petani yang dipercayainya dengan imbalan petani penjaga tersebut boleh menanam apa saja kecuali ikut dalam program pembinaan dari Lembaga pemerintah maupun LSM, sebab dikhawatirkan menimbulkan keruwetan dibelakang hari.

Petani penjaga HkM yang hak garapnya dipegang oleh orang tidak berdomisili dekat dengan HkM memperoleh kesulitan menghubungi pemilik atau pemegang hak garapnya. Kalaupun dapat dihubungi pemegang hak garap semacam itu sukar menyetujui lahan HKm diikutkan dalam program. Mereka khawatir selama berlangsungnya program akan disertai dengan penertiban pemegang hak garap. Tentu hal ini akan sangat merugikan mereka.

\section{Penanganan Porang Pasca Panen}

1. Produk olahan porang

Pengolahan porang terutama dilakukan untuk mendapatkan komponen glukomanan nya. Produk porang yang biasa diolah dan dipasarkan dari umbi segar adalah chips, tepung porang 
(konjac flour) dan tepung glukomannan (konjac glucomannan).

Pengolahan umbi porang menjadi produk kering/antara, seperti chips dan tepung merupakan upaya untuk menginaktivasi enzim yang dapat merusak glukomanan bila disimpan dalam bentuk segar. Selain itu, bentuk kering juga lebih ringkas dan lebih tahan lama disimpan dan praktis untuk diolah lebih lanjut. Pada pembuatan chips, umbi segar disortasi lebih dahulu, dengan memisahkan umbi yang tidak rusak/cacat, kemudian dikupas, dicuci dan direndam dalam air bila menunggu proses berikutnya untuk mencegah terjadinya pencoklatan. Umbi selanjutnya diiris tipis dengan ketebalan 0,5-1,0 cm, lalu direndam dalam larutan garam $5 \%(\mathrm{~b} / \mathrm{b})$ dengan perbandingan $1 \mathrm{~kg}$ umbi dengan 3 liter air selama 24 jam (Haryani dan Hargono 2008) untuk melarutkan kristal oksalat dan menetralkan senyawa alkaloid (konisin) yang berasa pahit. Irisan umbi kemudian bilas dengan air sampai bersih, lalu dijemur selama dua hingga tiga hari (30 jam) atau dikeringkan dalam oven pada suhu 70 oC selama 16 jam sampai kadar air $<12 \%$. Namun pengeringan chips dengan sinar matahari dilaporkan memberikan kandungan glukomanan yang lebih tinggi $(22,07 \%)$ dibandingkan dengan pengeringan oven $(18,15 \%)$ (Koswara 2013). Chips kering selanjutnya dapat digiling menjadi tepung porang yang diharapkan memiliki kandungan glukomanan tinggi, kalsium oksalat rendah dan warna putih/ cerah. Tingkat kehalusan tepung porang ini sekitar 40-60 mesh dan merupakan tepung porang kasar.

Untuk memisahkan glukomanan dari komponen lain yang terdapat pada tepung (pati, serat, kalsium oksalat, dan lain-lain), proses pemurnian (purifikasi) dapat dilakukan dengan cara mekanis dan kimia. Tepung hasil pemurnian ini disebut tepung glukomanan. Cara pemurnian mekanis, meliputi penggerusan/penggilingan dengan peniupan dan penggerusan dengan pengayakan dan penyosohan (Koswara 2013). Prinsip pemisahan dengan peniupan (hembusan) adalah berdasarkan bobot jenis dan ukuran molekul glukomanan yang lebih besar serta tekstur lebih keras dibandingkan dengan komponen tepung lainnya, sehingga akan jatuh dekat dengan pusat kipas (blower) dan mudah untuk dipisahkan. Pemisahan dengan ayakan menyebabkan fraksi glukomanan yang memiliki bobot lebih besar akan tinggal di bagian atas ayakan, sedangkan fraksi tepung yang halus akan lolos. Demikian pula pada pemisahan dengan penyosohan yang dilengkapi dengan ayakan dan alat penghisap yang berukuran 0,5-0,8 $\mathrm{mm}$, dapat menghisap komponen tepung yang lebih halus dan ringan bobotnya, sementara glukomanan yang bobotnya lebih besar akan terkumpul tepat di bawah ayakan.

Selain cara mekanis, pemisahan glukomanan dapat dilakukan dengan cara kimia meskipun relatif lebih rumit dan mahal (Koswara, 2013) Komposisi dan standar mutu chips/tepung porang Tepung porang kasar mengandung 49-60\% glukomanan, $10-30 \%$ pati, $2-5 \%$ serat kasar, $5-14 \%$ protein, 3-5\% gula reduksi, 3,4-5,3\% abu, lemak dan vitamin yang cukup rendah (Johnson 2007 dalam Mulyono 2010). Tepung ini biasanya berwarna krem sampai sedikit coklat dengan aroma amis yang khas (Wang dan Johnson 2003). Standar mutu chips/ tepung porang yang ditetapkan secara nasional (SNI) telah tersedia dan terdapat dua kategori mutu untuk chips/tepung porang (Tabel 2). Penggunaan tepung porang sebagai bahan baku/campuran pangan, harus memenuhi standar untuk bahan pangan (food grade) internasional, seperti yang berlaku di Amerika Serikat, yakni kadar glukomannan $=80 \%$, berwarna putih, berukuran kecil, mudah larut dalam air dingin atau panas, viskositas larutan tinggi $(1 \%$ larutan $=$ $16.000 \mathrm{cps})$, kadar

Tabel 2. Persyaratan mutu chips/tepung porang (iles-iles)

\begin{tabular}{|l|l|l|}
\hline Kriteria & Mutu I & Mutu II \\
\hline Kadar air $(\%)$ & Maksimum 12\% minimum & Maksimum 12\% minimum \\
Kadar mannan kering $(\%$ bb) Benda asing (\% & $35 \%$ maksimum 2 tidak ada & $15 \%$ maksimum 2 tidak ada \\
bb) & & \\
Iles-iles cacat & & \\
\hline
\end{tabular}

Sumber: BSN (1989) 
2. Pemanfaatan tepung porang dan tepung glucomannan

Tepung porang dapat dimanfaatkan untuk berbagai keperluan, di antaranya pangan fungsional, pakan ternak, pengikat air, bahan pengental, penggumpal atau pembentuk gel dan makanan diet rendah lemak dan kalori, terutama karena sifat kelarutan glukomanan nya yang tinggi di dalam air (Wang dan Johnson 2003). Sebagai bahan pangan, tepung porang dapat diolah menjadi konnyaku (mirip tahu) dan shirataki (berbentuk mie) yang cukup terkenal di Jepang, China, dan Taiwan dan relatif mahal harganya.

Di Indonesia, beberapa penelitian pemanfaatan tepung porang juga telah dilakukan. Yuwono (2010) melaporkan bahwa tepung porang dapat digunakan sebagai bahan campuran (komposit) dalam pembuatan beras tiruan. Demikian pula pada pembuatan mie instan, penambahan $1 \%$ tepung porang dapat meningkatkan kandungan protein, lemak, pati, serat dan pengembangan mie (Ika 2011). Sifat larutan tepung

Porang yang kental juga dapat dimanfaatkan sebagai penstabil es krim untuk memperbaiki teksturnya. Semakin tinggi konsentrasi tepung porang, semakin lama resistensi es krim terhadap pelelehan atau semakin sulit untuk meleleh (Kalsum 2012). Tepung porang juga dapat digunakan sebagai bahan pengenyal (gelling agent) sehingga berpeluang untuk menggantikan boraks yang berisiko terhadap kesehatan (Haryani dan Hargono 2008). Salah satunya adalah pada pembuatan tahu, yakni penggunaan tepung porang 110-190 g untuk 220 g biji kedelai yang ditambahkan ke dalam filtrat/sari kedelai pada kondisi pH 9-10. Selain itu juga dapat digunakan sebagai bahan pengikat pada pembuatan sosis ayam yang dicampur dengan maizena sebagai bahan pengisi dengan proporsi 2\%:22\% (Anggraeni et al. 2014).

Penggunaan tepung porang yang sudah dimurnikan (tepung glukomannan) lebih luas lagi pada berbagai produk makanan (Tabel 3). Sejak tahun 1994, tepung glukomannan disetujui sebagai bahan tambahan makanan (food additive) dalam daftar Food Chemical Codex (FCC) dan dianggap aman oleh Food, Drug and Cosmetics Act Amerika Serikat (Zhang et al. 2005). Penggunaan tepung glukomanan.

Tabel 3. Penggunaan dan fungsi tepung glukomanan pada berbagai jenis makanan

\begin{tabular}{|c|c|}
\hline Penggunaan & Fungsi Utama \\
\hline $\begin{array}{l}\text { Produk Tepung } \\
>\quad \text { Mie Instan } \\
>\quad \text { Pembungkus beku }\end{array}$ & $\begin{array}{l}>\text { Menyerap dan menyimpan air, meningkatkan elastisitas } \\
>\text { Menahan kerusakan akibat siklus pembekuan/pencairan }\end{array}$ \\
\hline $\begin{array}{ll}\text { Produk susu } \\
> & \text { Yogurt } \\
> & \text { Pudding } \\
> & \text { Es krim } \\
\end{array}$ & $\begin{array}{l}>\text { Stabilisasi } \\
>\text { Pengental, pemberi rasa di mulut } \\
>\text { Menahan kerusakan akibat pembekuan dan pencairan }\end{array}$ \\
\hline $\begin{array}{l}\text { Produk roti } \\
>\quad \text { Roti }\end{array}$ & $>$ Pengembangan adonan dan meningkatkan volume roti \\
\hline$>$ Gel air pada makanan penutup (dessert) & $>$ Pembentuk gel \\
\hline $\begin{array}{l}\text { Minuman } \\
>\quad \text { Minuman kaya serat } \\
>\quad \text { Jus }\end{array}$ & $\begin{array}{l}>\text { Pengental, pemberi rasa di mulut } \\
>\text { Pengental, pemberi rasa di mulut }\end{array}$ \\
\hline$>$ Jelli & $>$ Penguat gel, memperbaiki tekstur \\
\hline $\begin{array}{l}\text { Daging dan ikan: } \\
>\text { Dikalengkan } \\
>\text { Daging giling } \\
>\text { Sosis } \\
>\text { Pengganti daging }\end{array}$ & $\begin{array}{l}>\text { Pembentuk gel } \\
>\text { Perekat/pengikat partikel daging } \\
>\text { Perekat/pengikat daging dan pengganti lemak } \\
>\text { Pengganti minyak dan lemak }\end{array}$ \\
\hline
\end{tabular}




\section{Nilai Ekonomi dan Analisis Usaha Tani}

Harga ubi segar yang telah layak dipanen untuk diambil glukomanan nya berkisar antara Rp. $3000-3.500 / \mathrm{kg}$. Namun apabila ubi tersebut diproses dan dikeringkan menjadi bentuk keripik (Chip), harganya menjadi Rp.17.500-22.000/kg, sementara apabila telah diproses lebih lanjut menjadi tepung glukomanan, harganya meningkat menjadi sekitar Rp125.000-150.000/kg. Harga ubi kecil, yang dihasilkan dari tanaman berumur 1-2 tahun dan digunakan sebagai bibit berkisar Rp.9.000-11.000/ kg. Harga ubi katak (bulbil) yang digunakan sebagai bibit adalah Rp25.000$30.000 / \mathrm{kg}$. Biji lepas kulit yang diperoleh dari buah tanaman yang telah mengalami pertumbuhan maksimal (berumur empat tahun) harganya berkisar Rp.40.000-50.000/kg. Oleh karena itu dalam budidaya porang, disarankan sebaiknya dilakukan pemisahan penggunaan lahan atau dilakukan tanam seri pada kawasan lahan yang tersedia dengan peruntukan yang berbeda- beda, yakni sebagian lahan untuk pembibitan sendiri, terpisah dengan lahan untuk pembesaran (produksi), sehingga dapat dilakukan pengaturan permanen secara rutin.
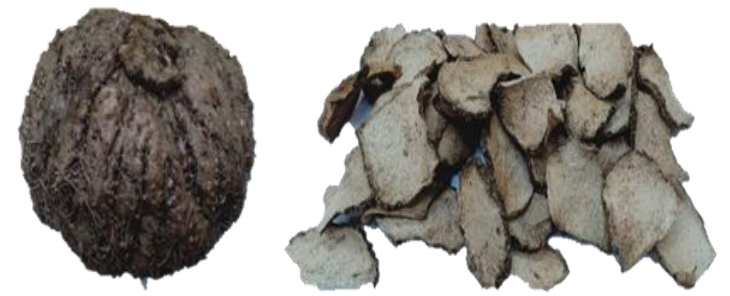

Gambar 3. Umbi porang yang masih utuh dan yang sudah diolah sederhana (dibuat diiris) seperti keripik

Dari aspek usahatani, budidaya tanaman porang juga cukup memberikan keuntungan bagi petani. Santosa et al. (2003) melaporkan bahwa pada sistem budidaya sederhana petani hanya menanam bulbil pada saat pertama kali berusaha tani porang. Selanjutnya setiap tahun bulbil akan tersebar dari tanaman secara alami. Petani memanen ubi pertama setelah tiga tahun dari waktu tanam pertama. Petani umumnya tidak melakukan pengelolaan tanaman kecuali penyiangan dan panen. Ternyata dengan budidaya sederhana tersebut, tanaman porang mampu memberi sumbangan $40-90 \%$ dari total pendapatan petani.
Selain secara finansial usahatani porang menguntungkan ke para petani, budidaya porang di bawah tegakan hutan industri (pohon jati, sono) Perum Perhutani melalui program PHBM juga memberikan keuntungan tidak langsung berupa terjaminnya keamanan pohon jati dari ancaman penjarahan. Permadi dan Latifah (2012) melaporkan bahwa pada kawasan hutan yang diusahakan porang, tingkat kerawanan kehilangan kayunya lebih rendah dari pada kawasan yang tidak diusahakan porang.

\section{Permasalahan Kelompok Tani Porang}

Namun demikian, berdasarkan hasil penelitian di lapangan ditemukan beberapa permasalahan utama yang saat ini dihadapi oleh petani porang, diantaranya:

\section{Permodalan}

Pada umumnya petani porang di Kec. Bayan masih menggunakan modal yang bersifat swadaya, sehingga untuk mengembangkan usahanya masih kesulitan, karena untuk mengembangkan usaha membutuhkan modal yang tidak sedikit.

\section{Pencurian umbi dan katak porang}

Bumingnya pemberitaan porang dengan harga yang menggiurkan, hal ini menimbulkan keresahan tersendiri di kalangan petani porang, dikarenakan lahan yang sudah ditanami porang banyak yang mencurinya sehingga menimbulkan kegagalan panen.

\section{Kebakaran Hutan}

Rentannya terjadi kebakaran di Kawasan hutan maupun Hutan Kemasyarakatan (HkM) terutama di musim kemarau merupakan persoalan yang cukup serius di kalangan petani porang Desa Sambik Elen. Terlebih Kecamatan Bayan mempunyai iklim tipe kering (D4-E) sehingga potensi kebakaran hutan besar terjadi.

\section{Kesimpulan}

Semua pemaparan di atas yang menjelaskan tentang potensi tanaman porang sebagai tanaman budidaya pada sistem hutan kemasyarakatan (HkM) kabupaten Lombok Utara dapat ditarik beberapa kesimpulan sebagai berikut:

1. Tanaman porang (Amorphophallus oncophyllus) sangat cocok dibudidayakan di kawasan HkM di Kabupaten Lombok Utara terutama di kawasan HkM di Desa Sambik Elen (hutan negara/hutan 
rakyat) karena mempunyai hubungan simbiosis mutualisme (saling menguntungkan sebagai sarana pengalihan orientasi dan mata pencaharian masyarakat di sekitar hutan dari Hasil hutan kayu ke hasil hutan non kayu dalam rangka peningkatan pendapatan dan kesejahteraan masyarakat. Selain itu kandungan nutrisi yang terdapat dalam tanaman porang terbilang kompleks terutama pati, glukomannan, kristal kalsium oksalat, serat kasar dan gula reduksi.

2. Pengolahan tanaman porang pasca panen menghasilkan beragam bentuk produk seperti: keripik (chip), tepung porang dan tepung glucomannan yang dapat digunakan sebagai bahan dasar tepung, mie instan dan produk makanan dan minuman lainnya.

3. Beberapa persoalan yang dihadapi petani porang secara umum di lokasi yakni: Permodalan, keamanan (sering terjadi pencurian tanaman porang di lahan), dan Kebakaran hutan.

\section{Ucapan Terima Kasih}

Penulis mengucapkan terima kasih kepada Fakultas Pertanian dan Lembaga Pengabdian Pada Masyarakat (LPPM) Universitas Mataram yang telah mendukung kegiatan pengabdian sehingga terlaksana dengan baik.

\section{Daftar Pustaka}

Arif, Arifin. 2001. Hutan dan Kehutanan. Yogyakarta: Kanisius.

Brown, D. 2000. Aroids: plants of Arum family. 2nd edition. Timber Press. Portland OR.

Chairiyah, N., N. Harijati, dan R. Mastuti. 2011. Kristal kalsium oksalat $(\mathrm{CaOx})$ pada porang (Amorphophallus muelleri Blume) yang terpapar dan tidak terpapar matahari. Jurnal Natural B. Universitas Brawijaya.

Chan, A.P.N. 2009. Konjact Part I. Cultivation to commercialication of components. J. Food Eng. 106:245-252.

Flach, M. and F. Rumawas. 1996. Plant resources of South-East Asia. 9. Plant yielding non-seed carbohydrates. Prosea. 237 pp.

Hadi, H,2016. Analisis Dampak Pengelolaan Hutan Kemasyarakatan (Hkm) Di Desa Sapit Kecamatan Suela Kabupaten Lombok Timur. Jurnal Geodika.2,(1): 9-21

Haryani, K. dan Hargono. 2008. Proses pengolahan ilesiles (Amorpho- phallus sp.) menjadi glukomannan sebagai gelling agent pengganti boraks. Momentum 4(2):38-41.

Haryanto, M. 2010. Hutan Kemasyarakatan (HKm) https: //blogmhariyanto. blogspot.com/2010/05

Herlina, R. dan S Siburian, 2016. Sistim Agroforestri pada lahan bekas hutan sagu di kampung Baraway Kabupaten Kepulauan Yapen Papua. Prosiding Seminar Hasil Penelitian Kanoppi. (Optimalisasi Pengelolaan Hutan Berbasis Agroforestri untuk Mendukung Peningkatan Produktifitas Kayu dan HHBK, serta Pendapatan Petani). Cisarua Bogor

https://www.researchgate.net/publication/331523137_Sist im_Agroforestri_pada_lahan_bekas_hutan_sagu_d i_kampung_Baraway_Kabupaten_Kepulauan_Yap en_Papua [accessed Feb 19 2020].

Indriyani, S., E. Ariesoesilaningsih, T. Wardiyati dan H. Purnobasuki. 2010. Hubungan faktor lingkungan habitat porang (Amorphophallusmuelleri Blume) pada lima agroforestri di Jawa Timur dengan kandungan oksalat umbi. Ringkasan Hasil Penelitian Dana Hibah.

Indriyani, S., E. Ariesoesilaningsih, T. Wardiyati dan H. Purnobasuki. 2011. A model of vrelationship between climate and soil factors related to oxalate content in porang (Amorphophallus muelleri Blume) corm. Biodiversitas 12(1):45-51.

Koswara, S. 2008. Kacang-kacangan. Diakses: 19 November 2012. www.ebookpangan.com

Koswara, S. 2013. Modul teknologi pengolahan umbiumbian. Bagian 2: Pengolahan umbi porang. Tropical Plant Curriculum (TPC) Project. USAID-SEAFAST Center-Bogor Agricultural University. http://sea- fast.ipb.ac.id/tpcproject/wp-content/uploads/2013/10/2-pen.

Mulyono, E. 2010. Peningkatan mutu tepung iles-iles (Amorphophallus oncophiyllus) (food grade: glukomannan $80 \%$ ) sebagai bahan peng- elastis mie (4\% meningkatkan elastisitas mie 50\%) dan pengental $(1 \%=16.000 \mathrm{cps})$ melalui teknologi pencucian bertingkat dan enzimatis pada kapasitas produksi $250 \mathrm{~kg}$ umbi/hari.

Nakata, P.A. 2003. Advancees in our understanding of calcium oxalate crystal formation and function in plants. Plant Science 164:901-909.

Peraturan Menteri Kehutanan Republik Indonesia Nomor : P.88/Menhut-Ii/2014 Tentang HUTAN KEMASYARAKATAN.

Peraturan Mentri Kehutanan Nomor P.37/menhutII/2007 Tentang Hutan Kemasyarakatan.

Permadi, D.B. dan L.P. Latifah. 2012. Potensi Agroforestri porang dalam menekan pencurian hutan jati dalam Budiadi, Permadi, D.P dan Latifah, L.P. (Ed.) Agroforestri porang, Masa depan hutan Jawa. Indonesian managing higher education for relevance and effeciency 


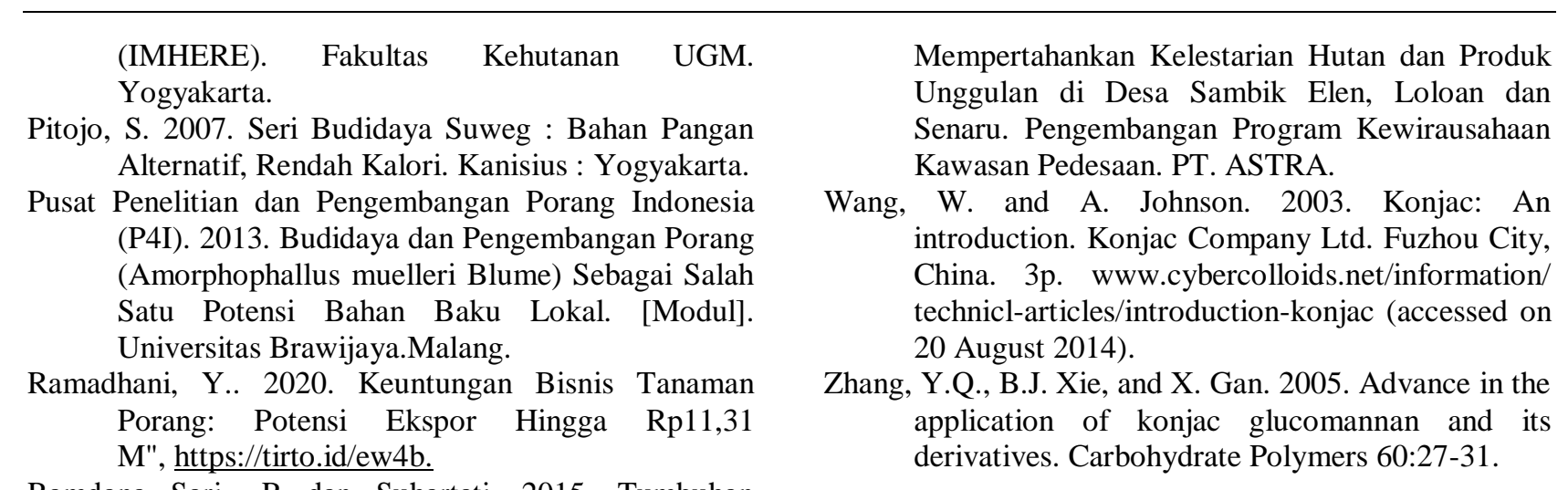

Ramdana Sari., R dan Suhartati. 2015. Tumbuhan Porang: Prospek Budidaya Sebagai Salah Satu Sistem Agroforestry Info Teknis Eboni. 12 (2), $97-110$

Rofik, K., R. Setiahadi, I. R. Puspitawati, M. Lukito, 2017. Potensi Produksi Tanaman Porang (Amorphophallus muelleri Blume) di Kelompok Tani MPSDH Wono Lestari Desa Padas, Kecamatan Dagangan, Kabupaten Madiun. Agritek: Jurnal Ilmu Pertanian, Kehutanan dan Agroteknologi. Vol.17 No.2, pp. 1411-5336.

Rosman, R. dan S. Rusli, 1991. Tanaman Iles-iles. Edisi khusus Littro. VII (2): 17-21.

Santosa, E., N. Sugiyama, S. Hikosaka, and S. Kawabata. 2003. Cultivation of Amorphophalluas muelleri Blume in timber forest of East Java. Japanese Journal of Tropical Agriculture 47(3):190-197.

Sugiyono. 2008. Metode Penelitian Kuantitatif Kualitatif dan $R \& D$. Bandung: Alfabeta

Sumarwoto, 2005. Iles-iles (Amorphophallus muelleri Blume); Deskripsi dan Sifat-sifat Lainnya. Biodiversitas, 6 (3) : 185-190.

Sumarwoto, 2011. Budidaya Iles-iles (Amorphophallus muelleri Blume). Di Bawah Tegakan Tanaman Hutan. Workshop Pengembangan Agroforestri dalam Mendukung Ketahanan Pangan dan Kesehatan Masyarakat. Program I-MHERE B.2.c. KP4, UGM. Yogyakarta.

Sumarwoto, 2012. Peluang Bisnis beberapa Macam Produk Hasil Tanaman Iles Kuning di DIY Melalui Kemitraan dan Teknik Budaya. Business Conference, Yogyakarta tanggal 6 Desember 2012.

Suprayogo, H., D.K. Hairiah, N. Wijayanto, Sunaryo, dan M. Noordwijk, 2003. Peran Agroforestri pada Skala Plot: Analisis Komponen Agroforestri sebagai Kunci Keberhasilan atau Kegagalan Pemanfaatan Lahan Indonesia. World Agroforestri Centre (ICRAF), Southeast Asia Regional Office. P0 Box 161 Bogor.

Suwardji, IGM Kusnarta, Ismail Yasin, Fahrudin. 2019. Pengembangan Agribisnis Porang Sebagai Alternatif Sumber Pangaan Lokal, 